Available online at website : http://journal.uinjkt.ac.id/index.php/dialektika

DIALEKTIKA: jurnal bahasa, sastra, dan pendidikan bahasa dan sastra Indonesia, 5(1), 2018, 21-33

\title{
PENGEMBANGAN BUKU PENGAYAAN NILAI-NILAI KONSERVASI HUMANISME DALAM PEMBELAJARAN MENULIS KREATIF CERITA FANTASI
}

\author{
Nonika Farahdila, Subyantoro \\ Universitas Negeri Semarang, Indonesia \\ E-mail: nfarahdila2@students.unnes.ac.id
}

\begin{abstract}
A good quality learning sources can support in the learning activity process to develop students' potential. Moreover, a good quality learning sources can attract and stimulate students' interest in learning. In accomplishing those objectives, books hold a strategic role. In that case, it is reasonable to make a development on an enrichment book which not only enriching knowledge, but also skills and shaping a positive personality in students. The purpose of this study is 1) to describe the needs of learners and educators of enrichment books; 2) drafting the enrichment book; and 3) outlining the expert's judgment of the enrichment draft. The content of conservation values of humanism is given in order to instill moral values. This research designs Research and Development $(R \& D)$ Thiagarajan model modified in 3 stages, such as define, design, and development. The results of this study are based on the results of questionnaire analysis needs of learners and educators who compiled into principles of book development. These principles include aspects of the material, aspects of presentation, aspects of graphics, aspects of language, aspects of learning materials needs creative writing fantasy story text, and aspects of the needs of the values of conservation of humanism.
\end{abstract}

Keywords: enrichment book; creative writing, literary fantasy; conservation values of humanism

\begin{abstract}
Abstrak: Sumber belajar yang berkualitas mendukung proses pembelajaran guna mengembangkan potensi peserta didik. Selain itu juga dapat menarik minat dan merangsang peserta didik untuk belajar. Untuk mencapai tujuan tersebut, buku memiliki peran strategis di dalamnya. Oleh karena itu, perlunya pengembangan buku pengayaan yang tidak hanya memperkaya pengetahuan tetapi juga mengembangkan keterampilan dan membentuk kepribadian positif peserta didik. Tujuan penelitian ini adalah mendeskripsi kebutuhan peserta didik dan pendidik terhadap buku pengayaan dan menyusun draf buku pengayaan serta menguraikan penilaian ahli terhadap draf buku pengayaan. Muatan nilai-nilai konservasi humanisme diberikan dengan tujuan untuk menanamkan nilai-nilai moral. Dengan desain Research and Development (R\&D) model Thiagarajan yang dimodifikasi dalam 3 tahap, yaitu define, design, dan development dihasilkan prinsip-prinsip pengembangan buku. Prinsipprinsip tersebut meliputi aspek materi, aspek penyajian, aspek grafika, aspek bahasa, aspek kebutuhan materi pembelajaran menulis kreatif teks cerita fantasi, dan aspek kebutuhan nilainilai konservasi humanisme.
\end{abstract}

Kata Kunci: buku pengayaan; menulis kreatif; cerita fantasi; nilai-nilai konservasi humanisme

Permalink/DOI: http:/ /dx.doi.org/10.15408/dialektika.v5i1.7930 


\section{Pendahuluan}

Pembelajaran bahasa Indonesia masih menjadi hal yang menarik untuk dikaji, terutama berkait dengan penyediaan sumber belajar. Penyediaan sumber belajar yang berkualitas dapat mendukung proses pembelajaran guna mengembangkan potensi dalam diri peserta didik. Selain itu, sumber belajar yang bermutu juga dapat menarik minat dan merangsang peserta didik untuk belajar. Dalam mencapai tujuan tersebut, buku memiliki peran strategis di dalamnya. Oleh karena itu, perlunya pengembangan buku pengayaan yang tidak hanya memperkaya pengetahuan tetapi juga mengembangkan keterampilan dan membentuk kepribadian positif dalam diri peserta didik. Hal tersebut sesuai Permendiknas ${ }^{1}$, Puskurbuk ${ }^{2}$, Sitepu $^{3}$, dan Kurniawan dan Subyantoro ${ }^{4}$ yang menyatakan bahwa buku pengayaan harus terdapat materi yang dibahas secara mendalam yang berlandaskan pada kekayaan nilai-nilai luhur bangsa di dalamnya.

Pada era digital seperti saat ini pun, buku masih dimanfaatkan sebagai salah satu sumber informasi dan pengetahuan. Sebagai sumber informasi tertulis, buku dapat dimanfaatkan untuk memperkaya pengetahuan dan wawasan seseorang. Dengan membaca buku, seseorang dapat mengetahui berbagai informasi yang belum diketahui sebelumnya. Bahkan, setelah membaca buku seseorang dapat memperoleh informasi/petunjuk yang dapat membantu memecahkan masalah dalam kehidupannya. Selain itu, dengan membaca buku, anak akan terpengaruh perkembangan minat, sikap sosial, emosi, dan penalarannya.

Dalam dunia pendidikan, buku memiliki peran yang penting untuk menunjang kegiatan pembelajaran. Kaitannya dengan kegiatan pembelajaran, buku berfungsi untuk mempermudah sekaligus memberikan gambaran pada pendidik maupun peserta didik dalam memahami materi pembelajaran yang akan diajarkan. Buku-buku yang dipakai sebagai salah satu sumber belajar dalam

\footnotetext{
${ }^{1}$ Peraturan Menteri Pendidikan Nasional Nomor 2 Tahun 2008 tentang Buku, (Jakarta: Biro Hukum dan Organisasi Departemen Pendidikan Nasional, 2008).

${ }^{2}$ Pusat Perbukuan Depdiknas, Pedoman Penulisan Buku Nonteks (Buku Pengayaan, Referensi, dan Panduan Pendidik, (Jakarta: Puskurbuk, 2008).

${ }^{3}$ B.P. Sitepu. Penulisan Buku Teks Pelajaran, (Bandung: Remaja Rosdakarya, 2014)

${ }^{4}$ Prasetyo Yuli Kurniawan dan Subyantoro, "Pengembangan Buku Pengayaan Menulis Teks Prosedur Kompleks yang Bermuatan Nilai-nilai Kewirausahaan”, (Seloka, Vol. 5 (1), 2016), h. 71-80.
} 
lingkungan pendidikan ini harus memuat berbagai informasi yang dapat membantu kegiatan pembelajaran dalam mencapai tujuan pendidikan nasional.

Sebagai sebuah karya sastra, teks cerita fantasi dipilih sebagai wahana penambah wawasan dan pengetahuan bagi peserta didik karena cerita fantasi dapat dimanfaatkan untuk menyampaikan pandangan/gagasan untuk orang lain. Hal itu dikarenakan, cerita fantasi menggambarkan dunia imajiner yang memiliki hubungan, baik langsung ataupun tidak dengan dunia nyata Di samping itu, cerita fantasi sebagai karya sastra merupakan gambaran kehidupan, termasuk di dalamnya adalah interaksi antarmanusia dan berbagai pengajaran tentang kehidupan. Sebagai cermin kehidupan nyata, cerita fantasi dapat menjadi salah satu media dalam mengembangkan dan menanamkan nilai-nilai serta etika (Subyantoro ${ }^{5}$ dan Nafisah dkk. ${ }^{6}$ ) .

Sebagai sebuah karya fiktif, cerita fantasi juga memberikan pengalaman, wawasan, dan pengetahuan tentang kehidupan. Sebagai sebuah fiksi naratif, cerita fantasi merupakan produk fantasi dan kreativitas manusia yang menyampaikan pencerminan dan kategorisasi budaya tertentu. Sebagai hasil dari kreativitas manusia. Ia memiliki keterkaitan dengan budaya dan kebiasaan masyarakat atau penulisnya. Melalui cerita fantasi inilah, pembaca dapat mengetahui kebiasaan atau budaya masyarakat tertentu termasuk di dalamnya memberikan pengajaran moral (Mengyi ${ }^{7}$ dan Trivedi $^{8}$ ).

Menghargai dan memperlakukan manusia sesuai harkat dan martabatnya sebagai makhluk Tuhan Yang Maha Esa, merupakan makna dan aktualisasi sila kedua pancasila. Hal tersebut, seharusnya menjadi pedoman hidup dalam bersikap dan berkelakuan untuk menghargai dan menghormati sesama manusia. Sudah selayaknya, bangsa Indonesia mengembangkan sikap saling mencintai sesama, saling tenggang rasa, dan tidak semena-mena terhadap orang lain, apalagi sampai melakukan tindak kekerasan dan kriminalitas.

Muatan nilai-nilai konservasi humanisme dipilih atas dasar maraknya berbagai kasus kekerasan dan tindakan kriminalitas yang terjadi dewasa ini.

\footnotetext{
${ }^{5}$ Subyantoro, "Model Bercerita untuk Meningkatkan Kecerdasan Anak: Aplikasi Ancangan Psikolinguistik", (Humaniora, Vol. 19, No. 3, 2007), h. 261-273.

${ }^{6}$ Nafisah, Durratun dkk., "Karakteristik Cerita Fantasi Anak Indonesia Periode 2000_-2010”, (Puitika, Vol.1, No.1, 2012), h. 1-10.

${ }^{7}$ Li Mengyi, Karen Murphy \& Carla M. Firetto, "Examining the Effects of Text Genre and Structure on Fourthand Fifth-Grade Students' High-Level Comprehension as Evidenced in SmallGroup Discussions”, (IJEP, Vol. 3, No.3, 2014), h. 205-234.

${ }^{8}$ Kaushik Trivedi, "Magic Realism: A Genre of Fantasy and Fiction", ( IJEE, July Vol. 2 Issue 3, 2014), h. 389-393.
} 
Fenomena-fenomena kekerasan dan tindakan kriminalitas tersebut tak jarang juga dilakukan oleh generasi muda. Fenomena-fenomena tersebut sama sekali tidak mencerminkan budaya bangsa Indonesia yang menjunjung tinggi nilainilai kemanusiaan, kedamaian, dan saling menghormati. Atas dasar itulah, perlu dilakukan pendidikan karakter yang diharapkan dapat mengatasi budaya kekerasan dan krisis moral yang terjadi (Jumarudin ${ }^{9}$, Khatib dkk. ${ }^{10}$, Khoiron ${ }^{11}$, Usman $\mathrm{dkk}^{12}$ ).

Penelitian ini didasarkan pada penelitian sebelumnya. Penelitian tentang cerita fantasi pernah dilakukan oleh Kurniawan dan Jismulatif ${ }^{13}$ dan Lestantiya dkk. ${ }^{14}$ Sementara itu, penelitian yang terkait dengan pengembangan buku pengayaan dilakukan oleh Fahmy dkk. ${ }^{15}$ dan Septarianto dan Subyantoro ${ }^{16}$. Penelitian yang berkaitan dengan nilai-nilai humanisme antara lain dilakukan oleh Sanusi ${ }^{17}$, Farida ${ }^{18}$, dan Usman dkk. ${ }^{19}$

Berdasarkan alasan-alasan tersebut, dilakukan penelitian dan studi pustaka yang relevan. Simpulan yang dapat dirumuskan adalah penelitian

\footnotetext{
${ }^{9}$ Abdul Gafur Jumarudin \& Siti Partini Suardiman, "Pengembangan Model Pembelajaran Humanis Religius dalam Pendidikan Karakter di Sekolah Dasar”, (Jurnal Pembangunan Pendidikan: Fondasi dan Aplikasi, Vol. 2, No. 2, 2014), h. 114- 129.

${ }^{10}$ Muhammad Khatib, Saeid Najafi Sarem, dan Hadi Hamidi, "Humanistic Education: Concerns, Implications and Applications", (Journal of Language Teaching and Research, Vol. 4, No. 1, 2013), h. 45 51 .

${ }^{11}$ Ahmad Mustamil Khoiron dan Eddy Sutadji, “Kontribusi Implementasi Pendidikan Karakter dan Lingkungan Sekolah terhadap Berpikir Kreatif serta Dampaknya pada Kompetensi Kejuruan”, (Jurnal Pendidikan dan Pembelajaran, Vol. 22, No. 2, 2015), h. 103-116.

${ }^{12}$ A. Hamdi Usman, Syarul A. S., dan Salman Z. Abidin, "Humanism in Islamic Education: Indonesian Reference", (IJAPS. Vol. 13, No. 1, 2017), h. 95-113.

${ }^{13}$ Otang Kurniawan dan Jismulatif, "Penggunaan Media Gambar untuk Meningkatkan Kemampuan Menulis Cerita Fantasi Mahasiswa PGSD FKIP Universitas Riau”, (Jurnal Pendidikan, Vol. 2, No. 01, 2014), h. 43-47.

${ }^{14}$ Febriyanti Anggie Lestantiya, Titik Harsiati \& Taufik Dermawan, "Pengembangan Instrumen Asesmen Menulis Kreatif Cerita Fantasi untuk Siswa Kelas VII SMP”, (Jurnal Pendidikan, Vol. 2 , No. 10, 2017), h. 1399-1408.

${ }^{15}$ Zulfa Fahmy, Subyantoro, dan Agus Nuryatin, "Pengembangan Buku Pengayaan Memproduksi Teks Fabel Bermuatan Nilai Budaya untuk Siswa SMP”, (Seloka, Vol. 4, No. 2 2015).

${ }^{16}$ Tomi Wahyu Septarianto dan Subyantoro, "Pengembangan Buku Pengayaan Menulis Teks Laporan Hasil Observasi yang Bermuatan Kearifan Lokal untuk Peserta Didik Kelas X SMA”, (Seloka: Jurnal Pendidikan Bahasa dan Sastra Indonesia, November 2015, 4[2]), h. 216224.

${ }^{17}$ Uci Sanusi, "Pembelajaran dengan Pendekatan Humanistik (Penelitian pada Mts Negeri Model Cigugur Kuningan”, (Ta’lim : Jurnal Pendidikan Agama Islam, Vol. 11, No. 2, 2013), h. 123 142 .

${ }^{18}$ Yushinta Eka Farida, "Humanisme dalam Pendidikan Islam”, (Jurnal Tarbawi, Vol. 12. No. 1 Januari - Juni, 2015).

${ }^{19}$ A. Hamdi Usman, Syarul A. S., dan Salman Z. Abidin. "Humanism in Islamic.... h. 95-113.
} 
pengembangan buku pengayaan bermuatan nilai-nilai konservasi humanisme dalam pembelajaran menulis kreatif teks cerita fantasi untuk melengkapi penelitian sebelumya. Tujuan penelitian ini adalah mendeskripsikan kebutuhan buku pengayaan, menyusun draf buku pengayaan, dan menguraikan penilaian ahli terhadap draf buku pengayaan.

\section{Metode}

Penelitian ini merujuk pada model pengembangan 4D Thiagarajan yang meliputi Define (pendefinisian), Design (perancangan), Development (pengembangan), dan Dissemination (diseminasi). Penelitian yang dilakukan peneliti dibatasi hingga tahap development (pengembangan) atas pertimbangan tujuan dan kebutuhan penelitian. Data penelitian terdiri atas 1) data kebutuhan buku pengayaan bermuatan nilai-nilai konservasi humanisme dalam pembelajaran menulis kreatif teks cerita fantasi berupa skor kecenderungan angket dan penyataan-pernyataan hasil wawancara, 2) data pengembangan buku pengayaan bermuatan nilai-nilai konservasi humanisme dalam pembelajaran menulis kreatif teks cerita fantasi SMP berupa kalimat pernyataan berisi karakteristik unsur-unsur penyusun buku pengayaan, 3) data uji validitas buku pengayaan bermuatan nilai-nilai konservasi humanisme dalam pembelajaran menulis kreatif teks cerita fantasi berupa skor penilaian dan saran perbaikan. Sumber data dalam penelitian ini di antaranya 1) sumber data analisis kebutuhan diperoleh dari 110 responden yang berasal dari tiga sekolah yang berbeda, yaitu SMPN 6 Semarang, SMPN 12 Semarang, dan SMPN 31 Semarang 2) sumber data pengembangan draf buku pengayaan diperoleh dari tabulasi instrumen analisis kebutuhan dan teori yang mendukung pengembangan draf buku pengayaan 3) sumber data validasi produk diperoleh dari penilaian draf buku pengayaan oleh dua orang dosen ahli bidang sastra dan bidang nilai-nilai konservasi humanisme.

\section{Pembahasan}

Hasil penelitian yang diuraikan meliputi 1) karakteristik kebutuhan buku pengayaan peserta didik dan guru, 2) pengembangan buku pengayaan, dan 3) penilaian dan perbaikan buku pengayaan. Uraian tersebut dijabarkan sebagai berikut. 


\section{Karakteristik Kebutuhan Peserta Didik dan Pendidik}

Karakteristik kebutuhan peserta didik dan pendidik terhadap buku pengayaan meliputi beberapa aspek, yaitu 1) kebutuhan materi, 2) kebutuhan penyajian, 3) kebutuhan grafika, dan 4) kebutuhan bahasa. Pada aspek kebutuhan materi, peserta didik dan pendidik membutuhkan buku yang lengkap, mudah dipahami, dengan sajian materi singkat serta muatan nilai-nilai konservasi humanisme berbentuk cerita. Pada aspek penyajian, dibutuhkan buku pengayaan yang runtut dan memiliki kepaduan antarbab. Pada aspek grafika peserta didik dan pendidik membutuhkan buku pengayaan yang menarik dengan tambahan ilutrasi. Pada aspek bahasa dibutuhkan buku pengayaan yang lugas, informatif, dan komunikatif sehingga mudah dipahami.

\section{Pengembangan Buku}

Bagian ini akan menguraikan 1) prinsip pengembangan buku pengayaan bermuatan nilai-nilai konservasi humanisme dalam pembelajaran menulis kreatif teks cerita fantasi dan 2) draf buku pengayaan bermuatan nilai-nilai konservasi humanisme dalam pembelajaran menulis kreatif teks cerita fantasi.

\section{Prinsip-prinsip Pengembangan}

Prisip-prinsip pengembangan buku pengayaan dirumuskan berdasarkan tabulasi instrumen analisis kebutuhan dan hasil wawancara. Prinsip tersebut dikembangkan berdasarkan empat aspek yaitu materi/isi, penyajian, grafika, dan bahasa.

\section{Aspek Materi/Isi}

Prinsip pengembangan yang digunakan pada aspek materi/isi yaitu, (1) kelengkapan materi berupa pengertian, struktur, kaidah bahasa, ciri-ciri, dan langkah menyusun teks cerita fantasi, (2) nilai-nilai konservasi humanisme yang dimuatkan adalah keteguhan, keadilan, kepedulian, dan kerja sama, (3) sajian materi teks cerita fantasi yang dibutuhkan adalah singkat, jelas, disertai gambar/ ilustrasi yang mendukung, dan (4) pengintegrasian nilai-nilai konservasi humanisme dalam semua komponen buku. Aspek-aspek tersebut dirumuskan berdasarkan prinsip relevansi, kebaruan, dan keruntutan.

\section{Aspek Penyajian}

Aspek penyajian disesuaikan dengan prinsip kemenarikan, keruntutan, dan kebaruan. Adapun prinsip pengembangannya, yaitu (1) penyajian materi 
teks dengan urutan contoh, teori, uraian, pembahasan, (2) penyajian struktur teks cerita fantasi berupa uraian dan tabel/diagram, (3) penyajian ciri-ciri dan kaidah bahasa berupa penyebutan perpoin disertai uraian dan contoh, (4) organisasi pengertian teks cerita fantasi berupa uraian pendapat ahli dan simpulan singkat, (5) penyajian langkah-langkah menulis kreatif berupa teori, contoh teks, dan pembahasan, serta (6) penyajian materi tambahan berbentuk cerita.

\section{Aspek Grafika}

Pengembangan buku pengayaan dalam aspek grafika mengacu pada prinsip kemenarikan, kesesuaian, dan konsistensi. Enam prinsip pengembangan aspek grafika meliputi (1) tebal buku 55-65 halaman, (2) buku berukuran A5 $(14,8 \mathrm{~cm} \times 21 \mathrm{~cm}),(3)$ pemilihan warna berupa warna-warna pastel (kuning muda, hijau muda, biru muda, dll), (4) jenis kertas sampul adalah soft cover, (5) ukuran dan jenis huruf yang digunakan adalah Calisto MT dan Garamond 12, dan (6) penyajian ilustrasi sampul berupa kegiatan menulis kreatif.

\section{Aspek Bahasa}

Prinsip pengembangan buku pengayaan aspek bahasa meliputi, (1) penggunaan istilah berupa istilah asing disertai kata serapan bahasa Indonesia, (2) kata sapaan yang digunakan adalah kalian, (3) judul buku pengayaan yaitu Kreatif Menulis Teks Cerita Fantasi Bermuatan Nilai Konservasi Humanisme, dan (4) pilihan kata dan penggunaan bahasa yang santai dan komunikatif. Prinsip pengembangan tersebut disesuaikan dengan prinsip kemudahan, kesesuaian kekomunikatifan, dan kebakuan.

\section{Draf Buku Pengayaan}

Draf buku pengayaan diuraikan dalam tiga komponen utama, yaitu sampul buku, bentuk fisik buku, dan isi buku. Isi buku diuraikan dalam tiga sub kategori, yaitu bagian awal, isi, dan penutup. Bagian awal menjelaskan informasi awal tentang buku, antara lain berisi halaman judul, halaman hak cipta, halaman prakata, dan halaman daftar isi. Bagian isi terdiri atas tiga bab, yaitu bab I, bab II, dan bab III. Bab I merupakan uraian materi teks cerita fantasi yang meliputi pengertian cerita fantasi, ciri-ciri cerita fantasi, struktur teks cerita fantasi, dan kaidah bahasa teks cerita fantasi. Adapun Bab II merupakan kaidah menulis kreatif teks cerita fantasi. Selanjutnya, Bab III berisi contoh-contoh teks cerita fantasi bermuatan nilai-nilai konservasi humanisme. Bagian akhir buku pengayaan terdiri atas glosarium, daftar pustaka, identitas penulis, identitas 
ilustrator, dan identitas layouter serta isi produk terdiri atas tiga bab, yaitu bab I, bab II, dan bab III.

\section{Penilaian dan Perbaikan Buku}

Penilaian dilakukan oleh dua orang dosen ahli terhadap bagian awal, isi, dan bagian akhir buku. Setiap bagian berisi penilaian aspek isi/materi, penyajian, grafika, dan bahasa. Bagian awal memperoleh skor 80,2 dan berkategori baik. Penilaian bagian isi memperoleh skor 76,97 dengan kategori baik. Penilaian bagian akhir adalah 76,7 dan berkategori baik. Saran perbaikan yang disampaikan para ahli antara lain, 1) judul buku dalam bagian prakata ditulis cetak miring bukan menggunakan tanda petik, 3) kata "secuil" pada identitas penulis diganti dengan yang baku, 3) sajian materi buku pengayaan teori, contoh, keterampilan menulis, dan 4) urutan materi buku secara keseluruhan dimulai dari konsep, contoh, dan praktik menulis.

Mengacu pada hasil penilaian dan saran serta masukan tersebut, peneliti melakukan perbaikan terhadap buku pengayaan. Perbaikan awal buku meliputi (1) perbaikan penulisan bagian prakata dan (2) penyesuaian daftar isi. Perbaikan bagian isi buku meliputi beberapa hal, di antaranya (1) perbaikan desain halaman judul bab, (2) perbaikan sajian materi, (3) perbaikan kolom ciri-ciri teks, (4) perbaikan sajian struktur teks cerita fantasi, (5) perbaikan sajian kaidah bahasa, (6) perbaikan kolom "Kamu Perlu Tahu", (7) perbaikan sajian kata ganti orang, (8) perbaikan kolom motivasi, (9) penyajian rangkuman, dan (10) perbaikan kolom "Sudahkah Menjadi Pribadi yang Peduli?" Perbaikan bagian akhir buku dilakukan pada komponen daftar pustaka dan penyajian profil layouter. Perbaikan dilakukan dengan mengubah penulisan sumber rujukan.

\section{Prospek Buku}

Prospek buku pengayaan yang dikembangkan, di antaranya 1) Pendamping buku teks yang memperkaya pengetahuan dan wawasan. Sajian buku pengayaan yang berisi contoh dan materi menulis kreatif teks cerita fantasi diharapkan menjadi alternatif bahan bacaan. Harapan tersebut sesuai Pusat Perbukuan Depdiknas ${ }^{20}$, Permendiknas ${ }^{21}$, Suryaman ${ }^{22}$, dan Sitepu ${ }^{23}$ bahwa buku nonteks pelajaran memiliki kedudukan sebagai buku yang dapat

\footnotetext{
${ }^{20}$ Pusat Perbukuan Depdiknas. Pedoman Penulisan ..... 2008

${ }^{21}$ Peraturan Menteri Pendidikan Nasional Nomor 2 Tahun 2008 tentang Buku....2008.

${ }^{22}$ Maman Suryaman, Penggunaan Bahasa dalam Buku Nonteks Pelajaran, (Makalah disajikan dalam Pelatihan Penulisan Buku Nonteks Pelajaran, Banten, 26-30 Maret, 2012).

${ }^{23}$ B.P. Sitepu. Penulisan Buku Teks.... 2014.
} 
melengkapi pendalaman materi dan penambahan wawasan bagi pembaca. 2) Langkah penanaman pendidikan karakter. Muatan nilai-nilai konservasi humanisme pada buku pengayaan dimaksudkan untuk menanamkan karakter positif pada peserta didik. Upaya tersebut dipenuhi dengan mengintegrasikan nilai-nilai konservasi humanisme dalam contoh teks, penyajian ilustrasi, penyajian kolom yang informatif, dan kata-kata motivasi.

Penanaman nilai tersebut perlu dilakukan pada peserta didik agar mereka setidaknya paham tentang nilai-nilai moral berupa jujur, hormat, menolong orang, adil, dan bertanggung jawab (Abidin ${ }^{24}$, Subyantoto ${ }^{25}$, dan Asriani dkk. ${ }^{26}$ ). 3) Sesuai untuk berbagai kalangan. Kendatipun buku pengayaan yang dikembangkan bertema nilai-nilai konservasi humanisme dan berisi cerita fantasi, buku pengayaan tersebut dapat digunakan berbagai kalangan. Pembaca tidak terbatas pada jenjang pendidikan, tingkat sosial, tingkatan kelas maupun latar belakang budaya yang berbeda. Materi yang dikembangkan dapat digunakan oleh berbagai kalangan dan tidak terbatas pada lingkup tertentu. Hal tersebut juga dinyatakan Pusat Perbukuan Depdiknas ${ }^{27}$ bahwa materi atau isi dari buku nonteks pelajaran dapat dimanfaatkan oleh pembaca dari semua jenjang pendidikan dan tingkatan kelas atau lintas pembaca, sehingga materi buku nonteks pelajaran dapat dimanfaatkan pula oleh pembaca secara umum.

\section{Kebaruan}

Pertama, kebaruan yang dimunculkan adalah muatan nilai-nilai konservasi humanisme dalam contoh-contoh teks cerita fantasi dan kata-kata motivasi. Teks cerita fantasi, sebagai sebuah karya sastra tidak hanya memberikan hiburan tetapi juga menciptakan pengalaman dan pengetahuan yang bisa dipelajari. Hal tersebut berarti bahwa sastra memiliki peluang untuk menjadikan seseorang memiliki pola pikir kritis tanpa harus melupakan aspek-aspek humanisme ${ }^{28}$.

Kedua, kebaruan buku pengayaan diintegrasikan pada komponen sampul dan prakata. Desain sampul disajikan dengan ilustrasi ksatria dan pasukan-

\footnotetext{
${ }^{24}$ Yunus Abidin, Pembelajaran Bahasa Berbasis Pendidikan Karakter, (Bandung : Refika Aditama, 2015).

${ }^{25}$ Subyantoro. "Model Bercerita....

${ }^{26}$ Asriani, Pity Asriani, Cholis Sa' dijah, dan Sa' dun Akbar, "Bahan Ajar Berbasis Pendidikan Karakter untuk Siswa Kelas IV Sekolah Dasar”, (Jurnal Pendidikan. Vol. 2 No. 11. 2017).

${ }^{27}$ Pusat Perbukuan Depdiknas, Pedoman Penulisan Buku Nonteks (Buku Pengayaan, Referensi, dan Panduan Pendidik, (Jakarta: Puskurbuk, 2008).
} 
pasukannya yang menunjukkan sikap persatuan dan tanggung jawab. Selain itu, warna sampul depan yang dipilih adalah warna biru muda dan hijau muda yang menunjukkan kedamaian dan keseimbangan (Pile dan Birren dalam Marsya dan Anggraita $^{29}$ ). Sementara itu, pada komponen prakata, disajikan kalimat-kalimat informatif tentang prinsip nilai-nilai konservasi humanisme. Buku pengayaan harus menyertakan ilustrasi yang dapat memberi kontribusi positif untuk pembentukan konsep diri atau self-concept pada diri anak yang sedang dalam masa pertumbuhan dan masa perkembangan ${ }^{30}$.

\section{Keunggulan dan Kelemahan}

Jika ditinjau dari segi fisik, beberapa keunggulan buku pengayaan bermuatan nilai-nilai konservasi humanisme dalam pembelajaran menulis kreatif teks cerita fantasi antara lain 1) praktis dan mudah dibawa karena buku dicetak dengan ukuran A5 (176 mm x $250 \mathrm{~mm}$ ) dengan ketebalan 72 halaman, 2) buku disajikan dengan sampul berjenis softcover yang ringan dan tidak terlalu tebal, 3) desain buku yang memadukan ilustrasi gambar, warna, dan tulisan sehingga menarik minat pembaca untuk mempelajari buku pengayaan tersebut. Hal ini sejalan dengan pendapat Septarianto dan Subyantoro yang menyatakan bahwa buku harus sesuai dengan prinsip kemenarikan yang meliputi gambar/ilustrasi sesuai, pemilihan warna pada tulisan maupun layout sampul dan isi buku ${ }^{31}$.

Ditinjau dari segi isi, beberapa keunggulan buku pengayaan di antaranya, 1) penyusunan buku pengayaan menyesuaikan dengan kompetensi dan pemahaman peserta didik SMP, 2) kelengkapan teori yang bersifat konstruktif dan menuntun pola pikir logis, kritis, dan kreatif karena materi disusun dengan pola pikir induktif, 3) langkah-langkah kerja yang sederhana dan aplikatif membuat peserta didik mampu menerapkannya dengan baik, 4) muatan nilai humanisme yang terintegrasi dalam ilustrasi, contoh teks, dan kata-kata motivasi merupakan upaya pendidikan karakter.

\footnotetext{
${ }^{29}$ IH Marsya dan AW Anggraita, "Studi Pengaruh Warna pada Interior Terhadap Psikologis Penggunanya, Studi Kasus pada Unit Transfusi Darah Kota X” (Jurnal Desain Interior, Vol. 1, No. 1, 2016), h. 44

${ }^{30}$ Galuh Nur Rohman, "Pengaruh Nilai Cerita Anak dan Kesusasteraan dalam Menciptakan Pendidikan Humanis Bagi Anak Indonesia” (Lingua. Vol. 1 No. 1, 2006), h. 44.

${ }^{31}$ Tomi Wahyu Septarianto dan Subyantoro, "Pengembangan Buku Pengayaan Menulis Teks Laporan Hasil Observasi yang Bermuatan Kearifan Lokal untuk Peserta Didik Kelas X SMA”, (Seloka: Jurnal Pendidikan Bahasa dan Sastra Indonesia, Vol.4, No.2, November 2015), h. $220-224$.
} 
Dalam proses pengembangannya, buku pengayaan bermuatan nilai-nilai konservasi humanisme dalam pembelajaran menulis kreatif teks cerita fantasi memiliki beberapa kelemahan. Kelemahan pertama adalah jumlah contoh teks cerita fantasi yang kurang beragam sehingga peneliti harus menyusun contoh teks yang sesuai dengan tema dan konsep buku pengayaan. Hal kedua adalah kesesuaian ilustrasi dengan tema dan konsep buku pengayaan. Kelemahan yang ketiga adalah kurangnya pengalaman peneliti dalam menyusun draf buku pengayaan.

\section{Penutup}

Berdasarkan hasil dan pembahasan, simpulan dalam penelitian ini yaitu analisis kebutuhan buku pengayaan menghasilkan karakteristik kebutuhan buku pengayaan yang digunakan sebagai dasar perumusan prinsip-prinsip pengembangan buku pengayaan dengan didukung teori yang relevan. Draf buku pengayaan terdiri atas tiga komponen utama, yaitu sampul buku, bentuk fisik buku, dan isi buku. Isi buku diuraikan dalam tiga sub kategori, yaitu bagian awal, isi, dan penutup. Penilaian diklasifikasikan atas tiga bagian yaitu awal, isi, dan akhir. Bagian awal memperoleh nilai rata-rata 80,2 dan berkategori baik, bagian isi 76,97 dan berkategori baik, serta bagian akhir 76,7 dan berkategori baik.

Saran yang dapat diberikan, yaitu 1) hendaknya buku pengayaan dapat dimanfaatkan oleh peserta didik maupun pendidik sebagai pelengkap buku teks pelajaran, 2) buku pengayaan bermuatan dapat digunakan untuk menanamkan pendidikan karakter karena bermuatan nilai-nilai konservasi humanisme, dan 3) perlu diadakan penelitian lebih lanjut untuk menguji keefektifan buku pengayaan bermuatan nilai-nilai konservasi humanisme dalam pembelajaran menulis kreatif teks cerita fantasi sehingga dapat digunakan dalam skala yang lebih luas.

\section{Daftar Pustaka}

Abidin, Y. Pembelajaran Bahasa Berbasis Pendidikan Karakter. Bandung. Refika Aditama. 2015.

Arif, M. "Islam Humanis, HAM, dan Humanisasi Pendidikan. Eksposisi Integratif Prinsip Dasar Islam, Kebebasan Beragama, Kesetaraan Gender, dan Pendidikan Humanis". Musawa. Vol. 15 No. 2. 2016. 
Asriani, P. Cholis S, dan Sa'dun A. "Bahan Ajar Berbasis Pendidikan Karakter Untuk Siswa Kelas IV Sekolah Dasar”. Jurnal Pendidikan. Vol. 2 No. 11. 2017.

Fahmy, Z., Subyantoro, dan Agus Nuryatin. "Pengembangan Buku Pengayaan Memproduksi Teks Fabel Bermuatan Nilai Budaya untuk Siswa SMP”. SELOKA. Vol. 4 No. 22015.

Farida, Y. E.. "Humanisme dalam Pendidikan Islam". Jurnal Tarbawi Vol. 12. No. 1 Januari - Juni. 2015.

Jumarudin, A.G. \& Suardiman, S.P. "Pengembangan Model Pembelajaran Humanis Religius dalam Pendidikan Karakter di Sekolah Dasar”. Jurnal Pembangunan Pendidikan: Fondasi dan Aplikasi. Vol. 2, No. 2. 2014.

Khatib, M. Saeid N. S., dan Hadi H.. "Humanistic Education: Concerns, Implications and Applications". Journal of Language Teaching and Research. Vol. 4, No. 1. 2013.

Khoiron, A. M.l dan Eddy S. "Kontribusi Implementasi Pendidikan Karakter dan Lingkungan Sekolah terhadap Berpikir Kreatif serta Dampaknya pada Kompetensi Kejuruan”. Jurnal Pendidikan dan Pembelajaran, Vol. 22, No. 2. 2015.

Kurniawan, O. dan Jismulatif. "Penggunaan Media Gambar untuk Meningkatkan Kemampuan Menulis Cerita Fantasi Mahasiswa PGSD FKIP Universitas Riau”. Jurnal Pendidikan. Vol. 2 No. 01. 2011.

Kurniawan, P.Y. dan Subyantoro. "Pengembangan Buku Pengayaan Menulis Teks Prosedur Kompleks yang Bermuatan Nilai-Nilai Kewirausahaan". Jurnal Seloka. Vol. 5 (1). 2016.

Lestantiya, F. A., Titik H. \& Taufik D. "Pengembangan Instrumen Asesmen Menulis Kreatif Cerita Fantasi Untuk Siswa Kelas VII SMP”. Jurnal Pendidikan, Vol. 2, No. 10. 2017.

Peraturan Menteri Pendidikan Nasional Nomor 2 Tahun 2008 tentang Buku. Jakarta: Biro Hukum dan Organisasi Departemen Pendidikan Nasional. 2008.

Marsya, IH dan AW Anggraita. "Studi Pengaruh Warna pada Interior Terhadap Psikologis Penggunanya, Studi Kasus pada Unit Transfusi Darah Kota X". Jurnal Desain Interior, Vol. 1, No. 1. 2016.

Mengyi, Li, Murphy, K. \& Firetto, C.M. "Examining the Effects of Text Genre and Structure on Fourthand Fifth-Grade Students' High-Level Comprehension as Evidenced in Small-Group Discussions". IJEP. Vol. 3 No.3. 2014. 
Nafisah, D. dkk. "Karakteristik Cerita Fantasi Anak Indonesia Periode 20002010”. Puitika. Vol.1, No.1. 2012.

Pusat Perbukuan Depdiknas. Pedoman Penulisan Buku Nonteks (Buku Pengayaan, Referensi, dan Panduan Pendidik). Jakarta: Puskurbuk. 2008.

Rohmah, Galuh N. "Pengaruh Nilai Cerita Anak dan Kesusasteraan dalam Menciptakan Pendidikan Humanis Bagi Anak Indonesia". Lingua. Vol. 1 No. 1. 2006.

Sanusi, Uci. "Pembelajaran dengan Pendekatan Humanistik (Penelitian pada

Mts Negeri Model Cigugur Kuningan)". Jurnal Pendidikan Agama Islam- Ta'lim. Vol. 11 No. 2. 2013.

Septarianto, T.W. dan Subyantoro. "Pengembangan Buku Pengayaan Menulis Teks Laporan Hasil Observasi yang Bermuatan Kearifan Lokal untuk Peserta Didik Kelas X SMA”. Seloka: Jurnal Pendidikan Bahasa dan Sastra Indonesia. 4 (2). November 2015.

Sitepu, B.P. Penulisan Buku Teks Pelajaran. Bandung: Remaja Rosdakarya. 2014.

Subyantoro. "Model Bercerita Untuk Meningkatkan Kecerdasan Anak: Aplikasi Ancangan Psikolinguistik". Humaniora. Vol. 19, No. 3. 2007.

Subyantoro,"Pengembangan Buku Pembelajaran Bahasa Indonesia Bermuatan Kesantunan Bahasa Lintas Budaya: Ancangan Psikolinguitik Pendidikan”. Kajian Linguistik dan Sastra.Vol. 24 (2). 2012.

Suryaman, M. Penggunaan Bahasa dalam Buku Nonteks Pelajaran. Makalah disajikan dalam Pelatihan Penulisan Buku Nonteks Pelajaran, Banten, 26-30 Maret. 2012.

Trivedi, K. "Magic Realism: A Genre of Fantasy and Fiction". IJEE. July Vol. 2 Issue 3. 2013.

Ugur, H. "Self-Awareness and Personal Growth: Theory and Application of Bloom's Taxonomy". Eurasian Journal of Educational Research, Issue 60.2015 .

Usman, A. Hamdi, Syarul A. S., dan Salman Z. Abidin. "Humanism in Islamic Education: Indonesian Reference”. IJAPS. Vol. 13, No. 1. 2017. 